\title{
CICLO "L" EM PROTEUS VULGARIS. I - MASSAS NUCLEARES EM ESFEROPLASTOS INDUZIDOS PELA PENICILINA*1
}

\author{
NIBER DA PAZ MOREIRA DA SILVA ** \\ e \\ MARIA LUIZA PALMEIRA
}

Instituto Oswaldo Cruz, Rio de Janeiro, Guanabara

(Com 27 figuras)

SUMÁRIo: Esferoplastos foram obtidos em Proteus vulgaris, cultivado em meio sintético simples, tendo como agente indutor a penicilina, em diferentes concentrações.

Estabelecida a dosagem ótima, de sensibilidade da bactéria ao antibiótico, para obtenção de "grandes corpos" do Ciclo "L", definidos, morfologicamente, como esferoplastos, foi feita a coloração de massas nucleares, em diversas fases do crescimento bacteriano. A colheita do material foi feita por impressão em lamínula, usando-se ácido ósmico como fixador, seguindo-se hidrólise clorídrica, com aquecimento, e coloração pela fucsina.

Dos resultados conseguidos ficou evidenciado: $10^{\circ}$ - a possibilidade de obtenção de "grandes corpos" em Proteus vulgaris em um meio sintético simples, a base de sais minerais e glicose; $2 .^{\circ}$ - que houve uma concentração ótima de penicilina para surgir o efeito indutor de esferoplasto, na fase logarítmica de crescimento; $3 .^{\circ}$ - a facilidade de coloração de massas nucleares nos esferoplastos em vários períodos de crescimento; $4 .^{\circ}$ - a reversão ao tipo morfológico normal, depois de 24 horas de crescimento no meio com o antibiótico; $5 .^{\circ}$ - modificação no crescimento do Proteus vulgaris em superfície de agar, com dose mínima de penicilina formando colônias localizadas.

UANDO Klieneberger $\left({ }^{10}\right)$ isolou $\mathcal{L}$ de Streptobacillus moniliformis formas bacterianas aberrantes, deu início a uma série de pesquisas visando ao estudo dessa alteração morfológica. Diferindo do tipo bacilar normal, foi o germe mantido em cultura pura, com a designação de "Forma L".
Contra a sua idéia primitiva de simbiose entre o Streptobacillus e aqueles corpos protoplasmáticos frágeis, que lhe lembravam pelo tipo de colônia e morfologia celular os PPLO, surgiu o conceito, aventado por vários pesquisadores, principalmente por Dienes $(2,3,4)$, de que essas formas es-

1 Recebldo para publicação a 26 de novembro de 1971.

* Trabalho do Laboratório de Bacteriologia, Departamento de Microbiologia e Imunologia do Instituto Oswaldo Cruz.

* Trabalho realizado com o auxílio do Conselho Nacional de Pesquisas. 
tranhas eram derivadas dos próprios bacilos. Ficou, então, provado que o Streptobacillus moniliformis poderia, espontaneamente, transformar-se, morfologicamente, quando semeado em certos meios de cultivo.

Inicialmente, Klieneberger - Nobel (11) usou somente caldo-soro, com o envelhecimento da cultura e passagem seriada em agar-soro, obtendo a Forma "L" do Streptobacillus. Posteriormente, foi verificado que outros gêneros de bactéria, sob a ação de agentes indutores e condições de cultivo especiais, também apresentavam a sua morfologia típica alterada. Assim, pleomorfismo aparecia em Klebsiella pneumoniae, segundo Grasset e Bonifás $\left({ }^{9}\right)$, em altas concentrações salinas; em Salmonella typhosa, Dienes et al ( $\left.{ }^{7}\right)$, usando anti-soro e complemento, viram formas aberrantes; em Corynebacterium $\mathrm{sp}$, crescendo em soro bovino normal e anaerobiose, Poetschke ( $\left.{ }^{14}\right)$ observou idêntica deformação e, ainda, Dienes e Zamecnik $\left(^{8}\right)$ conseguiram Forma "L" em Salmonella typhimurium e Haemophilus influenza sob a ação de glicina, metionina e fenilalanina.

Um dos agentes indutores mais utilizados para a obtenção de Forma "L" tem sido a penicilina - e antibióticos relacionados. Usada por Dienes $\left.{ }^{6}{ }^{6}\right)$ em vários gêneros bacterianos e em diferentes condições de cultivo, ligadas, principalmente, à composição do meio.

Afastando o emprego dos meios naturais iniciais, Medill e O'Kane ( ${ }^{12}$ ) usaram meio sintético, enriquecido com aminoácidos e solidificado com agar, para ter, sob a ação da penicìlina, colônias de Proteus em Forma "L". Também, Abrams ( ${ }^{1}$ ) empregou caldo-casamino acidos com penicilina e muitos outros tentaram induzir Forma "L", associando o antibiótico ao meio que era, geralmente, rico em substâncias nutritivas.

Procuramos, neste trabalho, estabelecer técnica simplificada para obtenção de Forma "L" em Proteus vulgaris, usando meio sintético, baseado no de Monod e Wollman (13), mínimo em nutrientes e solidificado com agar, comparando-o com o meio empregado por Abrams ( $\left.{ }^{1}\right)$. Paralelamente, procuramos determinar a concentração ótima de sensibilidade da amostra à penicilina, depois de verificar certa disparidade nas doses comumente empregadas. Finalmente, obtida a forma de transição no Ciclo " $L$ ", definida, morfologicamente, como esferoplasto, fizemos a evidenciação de massas nucleares, em diferentes fases do crescimento bacteriano, por hidrólise clorídrica e coloração simples.

\section{MATERIAL E MÉTODOS}

Amostra: Proteus vulgaris, isolada de água de esgoto (Coleção IOC, n. ${ }^{\circ} 2.375$ ).

Meios de cultura: Caldo-simples, Agarsimples, Caldo-coração. Meio Monod e WolIman (13), modificado e solidificado com agar:

$\begin{array}{llrr}\mathrm{KH}_{2} \mathrm{PO}_{4} \ldots \ldots \ldots \ldots \ldots \ldots & 1,5 & \mathrm{~g} \\ \mathrm{Na}_{2} \mathrm{HPO}_{4} \cdot 2 \mathrm{H}_{2} \mathrm{O} \ldots \ldots \ldots & 16,5 & \mathrm{~g} \\ \mathrm{SO}_{4} \mathrm{Mg} \cdot 7 \mathrm{H}_{2} \mathrm{O} \ldots \ldots \ldots \ldots & 0,2 & \mathrm{~g} \\ \mathrm{NH}_{4} \mathrm{Cl} \ldots \ldots \ldots \ldots \ldots \ldots \ldots & 2,0 & \mathrm{~g} \\ \mathrm{Cl}_{2} \mathrm{Ca} \ldots \ldots \ldots \ldots \ldots \ldots & 0,01 & \mathrm{~g} \\ \mathrm{SO}_{4} \mathrm{Fe} \cdot 7 \mathrm{H}_{2} \mathrm{O} \ldots \ldots \ldots \ldots & 0,0005 \mathrm{~g} \\ \text { Agua destilada } \ldots \ldots \ldots & 1000 \mathrm{ml}\end{array}$

pH 7.5, esterilizar $121^{\circ} \mathrm{C}-15$ minutos. Adicionar glicose a $0,4 \%$ (esterilizada por filtração) e agar (Difco) a 1,5\%.

Meio Abrams (1) (CAA - agar casamino-ácidos): $\mathrm{K}_{2} \mathrm{HPO}_{4}-16 \mathrm{~g} ; \mathrm{KH}_{2} \mathrm{PO}_{4}-2$ $\mathrm{g}$; citrato de sódio . $5 \mathrm{H}_{2} \mathrm{O}-1 \mathrm{~g} ; \mathrm{MgSO}_{4}$. 
$7 \mathrm{H}_{2} \mathrm{O}$ - 0,2 g; nicotinamida - $35 \mathrm{mg}$; casamino-ácidos - $10 \mathrm{~g} ; \mathrm{OH}_{2}$ destilada - 1.000 $\mathrm{ml}$; agar $-1,1 \%$.

Antibiótico: Penicilina G-potássica cristalina Squibb - 5.000.000 U.

Técnica - Em uma série de experiências complementares procuramos:

a) Verificação da sensibilidade do germe à penicilina em estudo comparativo, usando o meio sintético e caldo simples;

b) Determinaçãó da dose mínima do antibiótico para induzir a formação de colônia tipo " $\mathrm{L}$ ".

a) Em experiências prévias, a amostra de Proteus vulgaris, recentemente isolada de água de esgoto, foi cultivada a $37^{\circ} \mathrm{C}$, em caldo simples e no meio Monod e Wollman, sintético, líquido, contendo ambos, concentrações de penicilina, variáveis de 100 a $600 \mathrm{U} / \mathrm{ml}$. Verificada a maior sensibilidade da bactéria para $500 \mathrm{U} / \mathrm{ml}$, considerouse esta concentração, como sendo a ótima para o trabalho. A aferição da sensibilidade foi feita por turbidimetria, em colorimetro Klett-Summerson, filtro n. 66 .

b) Obtenção de colônias tipo "L" -

Preparadas as placas com o meio sintético solidificado, contendo a penicilina na concentração desejada, foi feita a semeadura de modo a cobrir toda a superfície com a cultura do Proteus, crescida em caldo-coração, durante 24 horas a $37^{\circ} \mathrm{C}$. Cbservadas em períodos de tempo variáveis, apareciam nas placas colônias, com as características de Forma " $L$ ", mesmo para dose do antibiótico muito inferior à escolhida para o trabalho (Figs. n. ${ }^{\circ} 19,20,21$, $22,23,24,25,26,27$ ).

\section{Técnica para coloração de massas nucleares}

Usamos o método de Smith (16), semeando a bactéria (cultivada em caldo-coração, durante 24 horas, a $37^{\circ} \mathrm{C}$ ) no meio sintético solidificado (Monod e Wollman) e no de Abrams, contendo $500 \mathrm{U} / \mathrm{ml}$ de penicilina, de modo a cobrir toda a superfície. Após 2, 4, 6, 8 e 24 horas de incubação a $37^{\circ} \mathrm{C}$, foram retirados blocos do agar $(5 \mathrm{~mm})$, com o crescimento, e feita a fi- xação em vapores de ácido ósmico a $2 \%$. Transferido, por impressāo, o crescimento bacteriano para uma lamínula, tratou-se - material com ácido clorídrico $\mathrm{N}$ a $60^{\circ} \mathrm{C}$, durante 5 minutos. Após lavagem com água destilada, foi colocado em formol (1\%) por 2 minutos, lavado, novamente, em água destilada e corado em 15 a 30 segundos, com solução aquosa de fucsina básica a $0,3 \%$. Depois de lavar em água destilada, a preparação foi montada com água em lâmina e selada com parafina. Examinada em Microscópio Reichert, ocular 10 e objetiva 100, imersão, filtro verde, as massas nucleares apareciam coradas em vermelho no citoplasma incolor ou levemente róseo.

\section{Resultados}

Trabalhando com amostra de Proteus vulgaris, nas condições descritas, variando as concentrações de penicilina de $100 \mathrm{U} / \mathrm{ml}$ a $600 \mathrm{U} / \mathrm{ml}$, o germe apresentou maior sensibilidade para a dose de $500 \mathrm{U} / \mathrm{ml}$. Nas concentrações de 100 e $200 \mathrm{U} / \mathrm{ml}$, depois de 5 e 7 horas de crescimento no meio de Monod e Wollman o aspecto do Proteus era normal, em cadeias longas, não sendo possível distinguir as massas nucleares, depois da hidrólise ácida e coloração (Figs. n.os 1,2 ). Com 300 a $400 \mathrm{U} / \mathrm{ml}$ do antibiótico, após 5 e 7 horas de incubação a $37^{\circ} \mathrm{C}$, as cadeias apresentavam deformação inicial com localização central, sem, entretanto, permitir evidenciar as massas nucleares (Figs. n.os $3,4,5,6$ ). Finalmente, usando $500 \mathrm{U} / \mathrm{ml}$ de penicilina, já nas 2 horas iniciais do tratamento, surgiram distorções nos bacilos, que se acentuavam com 4 horas. No fim de 6 e 8 horas de crescimento, apareciam os "grandes corpos", resultantes da modificação da parede da célula bacteriana, contendo as massas nucleares coradas e bem visí- 
veis nos dois meios usados (Figs. n. os $7,8,9,10)$. E interessante observar que a técnica empregada apresentou idênticos resultados, tanto no meio de Abrams, enriquecido de nutrientes, como no sintético de Monod e WolIman, modificado, e mínimo em substâncias nutritivas. (Figs. n.os 7, 8, 9, $10,11,12,13,14)$.

Observadas as culturas depois de 24 horas de crescimento, verificou-se a reversão ao tipo morfológico bacilar, em ambos os meios, com a ausência de cadeias no meio de Monod e Wollman, restando, ainda, nas preparações alguns esferoplastos (Figs. n.os $15,16)$.

Numa tentativa de observar o comportamento da bactéria diante de alta dose de penicilina, seguimos a mesma técnica, empregando $10.000 \mathrm{U} / \mathrm{ml}$ e verificamos o aparecimento dos esferoplastos logo no início da incubação (Fig. n. ${ }^{\circ}$ 17); desaparecendo os bacilos quase totalmente com 6 horas e, no fim das 24 horas, não houve reversão e, sim, explosão dos esferoplastos, ficando no preparado um material de aspecto granular (Fig. n. ${ }^{0} 18$ ).

\section{Estudo macroscópico das colônias}

Em experiência complementar, tentamos verificar a menor dose de penicilina que induziria a formação de colônia tipo "L". Usando, sòmente, 12 $\mathrm{U} / \mathrm{ml}$, conseguimos um crescimento localizado, divergindo completamente do "véu" invasor, característico do Proteus, e observado na amostra empregada.

Inicialmente, o desenvolvimento foi mínimo, visível no fim de 7 dias nas colônias limitadas, isoladas ou confluentes e de bordo elevado (Fig. n. $\left.{ }^{\circ} 19\right)$. Com 15 e 18 dias granulações internas surgiram, tendo em algumas, crescido colônias secundárias (Figs. n. ${ }^{\circ}$ 20, 21, 22, 23, 24, 25, 26, 27).

\section{Discussão}

As observações descritas neste trabalho, estão baseadas em estudo morfológico da bactéria e das culturas, sob a ação da penicilina.

As Formas "L" de Proteus e de outras espécies foram descritas, em revisão detalhada, por Dienes $\left(^{5}\right)$. Considera ele as Formas "L" í́picas, correspondentes à bactéria sem a parede celular, e envolvida somente, pela membrana citoplasmática ou tendo, além desta, presente na célula, a parede externa altamente alterada.

O estudo de Formas " $L$ " de Proteus é de particular interesse, desde que, nesta espécie, várias amostras intermediárias entre a bactéria e a Forma "L", têm sido isoladas $\left(^{6}\right)$. Segundo Dienes $\left(^{6}\right)$, a tendência para a variação nas propriedades da parede celular é aparente no Proteus, durante o crescimento normal da bactéria, assim como no desenvolvimento da Forma "L". Quando exposto à penicilina, o Proteus produz 2 tipos de Forma "L", distintos em suas propriedades: o designado como tipo $A$, apresentando apenas a membrana citoplasmática, $\mathrm{e}$ - $B$, possuindo, além da membrana, uma parede celular carente de rigidez.

Salton $\left({ }^{15}\right)$ confirma que a formação de esferoplastos em bacilos Gram negativos, resulta de um enfraquecimento da parede celular externa, mais do que de sua remoção. Podem ser 
obtidos pela ação direta da lisozima sobre componentes glicosaminopeptídeos ou, indiretamente, pela inibição da biosíntese do mucopeptídeo pela penicilina. Uma das características comumente encontradas em esferoplastos, induzidos por carência de ácido diamino-pimélico, ou por crescimento em presença de penicilina ou glicina, é a formação de grande região vacuolar, onde a parede deficiente fica separada da membrana citcplasmática.

No nosso trabalho, acreditamos ter ccnseguido o tipo $B$ de Forma " $L$ " para a bactéria estudada, porque observamos que as células submetidas aos detalhes da técnica para coloração de massas nucleares, conservavam as formas arredondadas sem rompimento e expulsão do conteúdo celular, como poderia acontecer se o mesmo estivesse contido, apenas, pela membrana citoplasmática. Entretanto, nas condições da técnica realizada, não cbservamos a região vacuolar, característica dos esferoplastos de parede cclular deficiente.

Extensa bibliografia sobre o modo de ação da penicilina, descreve a ligação do antibiótico, bloqueando locais na periferia da célula bacteriana. Admite-se que as zonas de ligação são áreas específicas para a síntese da parede basal, e que, esta síntese cessa quando as zonas são ocupadas pelo antibiótico. Há uma velocidade de recomposição da parede, muito rápida após a retirada da penicilina do meio de cultura. Este fenômeno deixa implícito que a penicilina combinada, evita a polimerização das unidades do mucopeptídeo, impedindo a formação da parede celular e que a polimeriza- ção recomeça, desde que os esferoplastos são transferidos para um meio sem a penicilina.

Nas experiências que realizamos, verificamos haver uma inter-relação entre as diferentes doses de penicilina usadas e a indução de Forma "L". O aparecimento de deformação do ccrpo bacteriano estava condicionado à dose do antibiótico, sendo progressiva com aumento da penicilina e em relação com o tempo de contato desta com o germe. Assim, o bloqueio da polimerização do mucopeptídeo se fazia, também, em função desses dois fatores que, geralmente, não têm sidos ressaltados.

Observamos, também, ser desnecessário retirar os esferoplastos para meio de cultura livre de penicilina, pois, com 24 horas de crescimento, junto com a pencilina, havia a reversão ao tipo bacilar normal. A reversão teve lugar na ausência de nutrientes exógenos, não tendo sido por nós pesquisada, ainda, a possibilidade da inativação da penicilina por enzima adaptativa ou por outros fatores.

\section{SUMMARY}

"L"-Forms of Proteus vulgaris Nuclear masses in spheroplasts having Penicillin as the inductor agent.

Spheroplasts were obtained from Proteus vulgaris, in sinthetic culture media, having Penicillin as the inductor agent, in different concentrations.

Once stablished the optimum dosage of sensibility of the bacterium, to the antibiotic to obtain "large bodies" from the "L" Cicle, morpholo- 
gically defined, as spheroplasts, nuclear masses, in several stages of the bacterial growth, were stained. The material was collected by cover-slip impression, using osmic acid as fixative, with heated cloric hydrolysis, and staining by fuchsin.

From the obtained results it became evident:

1 - the possibility of obtaining "large bodies" from Proteus vulgaris in a simple sinthetic culture medium, composed basically of mineral salts and glucose;

2 - that there existed an optimum concentration of Penicillin to induce the formation of spheroplasts, in the logarithmic growth fase;
3 - the ease by which the nuclear masses stain in the spheroplasts in several periods of growth;

4 - the reversion to the normal morphological type, after 24 hours of growth in culture medium containing the antibiotic;

5 - changes in the growth of Proteus vulgaris in agar surface, with a minimum Penicillin dose, forming localized colonies.

\section{AGRADECIMENTO}

Os autores agradecem ao Sr. José de Carvalho Filho, pela execução das fotografias.

\section{REFERÊNCIAS BIBLIOGRÁFICAS}

1 - ABRAMS, R. Y., $1955^{\circ}$ - A method for the cultivation of $\mathrm{L}$ forms in liquid media, J. Bact., 70 (2) : 251.

2 - DIENES, L., 1939 - "L" organisms of Klieneberger and Streptobacillus moniliformis, J. Infect. Dis., 65: 2442.

3 - DIENES, L., 1939 - "L" type variant forms in cultures of various bacteria, Proc. Soc. Exptl. Biol. Med., 42: 636640.

4 - DIENES, L., 1940 - Origin of L type colonies in Bacterial cultures, Proc. Soc. Exptl. Biol. Med., 43: 703-704.

5 - DIENES, L., 1970 - Morphology and reproductive processes of the " $L$ " forms of bacteria with a note on the relationship to mycoplasma, pg: 285312. In J. T. Sharp (ed.), The role of mycoplasmas and " $L$ " forms of bacteria in disease, Charles C. Thomas, Springfield, Ill.

6 - DIENES, L., 1970 - Permanent alterations of the L-Forms of Proteus and Salmonella under various conditions, J. Bact., 104 (3) : 1.369-1.377.

7 - DIENES, L., WEINBERGER, H. J. e MADOFF, S., 1950 - Serological Reactions of $\mathrm{L}$ type cultures isolated from Proteus, Proc. Soc. Exptl. Biol. Med., 75 (2) : 409-412.

8 - DIENES, L. e ZAMECNIK, P. C., 1952 - Transformation of bacteria into $\mathrm{L}$ forms by amino acids, J. Bact., 64: 770-771.

9 - GRASSET E. e BONIFAS, V., 1955 Sur l'obtention de formes $L$ de Klebsiella pneumoniae en milieu liquide et chez la souris sous l'action de la pénicilline. Schweiz. allgem. Pathol. u. Bakt., 18 (5) : 1.074-1.086.

10 - KLIENEBERGER, E., 1935 - The natural ocurrence of pleuropneumonialike organisms in apparent symbiosis with Streptobacillus moniliformis and other bacteria, J. Path. Bact., 40. 93-105. 
11 - KLIENEBERGER-NOBEL, E., 1960 In "The bacteria", Vol. I: 361-385, Academic Press, N. Y. e London.

12 - MEDILL, M. A. e O'KANE, D. J., 1954 - A synthetic medium for the " $L$ " type colonies of Proteus, J. Bact. 68 (5) : 530-533.

13 - MONOD, J. e WOLLMAN, E., 1947 L'inhibition de la croissance et de l'adaptation enzymatique chez les bactéries infectées par le bactériophage, Ann. Inst. Pasteur, 73 (10): 937-956.
14 - POETSCHKE, G., 1955 - On L-type Growth of Corynebactera, Int. Congr. Microbiol., 6 th Congr., Rome 1953. Rept. Proc., 1 (1) : 142-148 (1955).

15 - SALTON, M. R. J., 1964 - "The Bacterial Cell Wall", Elsevier Publishing Company, Amsterdam, London. N. Y.

16 - SMITH, A. G., 1950 - Electron and Light microscopic Studies of Bacterial Nuclei. II - An Improved Staining Tecnique for the Nuclear chromatin of Bacterial Cells. J. Bact., 59: 575-587. 


\section{ESTAMPA I}

Fig. 1 - Proteus vulgaris em Méio de Monod e Wollman, com $100 \mathrm{U} / \mathrm{ml}$ de penicilina e 5 hs de crescimento a $37^{\circ} \mathrm{C}$ - Coloração de massas nucleares (Smith) (1440 X).

Fig. 2 - Proteus vulgaris em Meio de Monod e Wollman, com $200 \mathrm{U} / \mathrm{ml}$ de penicilina e 7 hs de crescimento a $37^{\circ} \mathrm{C}$ - Coloração de massas nucleares (Smith) (1440 X).

Figs. 3 e 4 - Proteus vulgaris em Meio de Monod e Wollman, com $300 \mathrm{U} / \mathrm{ml}$ de penicilina e $7 \mathrm{hs}$ de crescimento a $37^{\circ} \mathrm{C}$ - Coloração de massas nucleares (Smith) (1440 X).

Figs. 5 e 6 - Proteus vulgaris em Meio de Monod e Wollman, com $400 \mathrm{U} / \mathrm{ml}$ de penicilina e 5 hs de crescimento a $37^{\circ} \mathrm{C}$ - Coloração de massas nucleares (Smith) (1440X). 

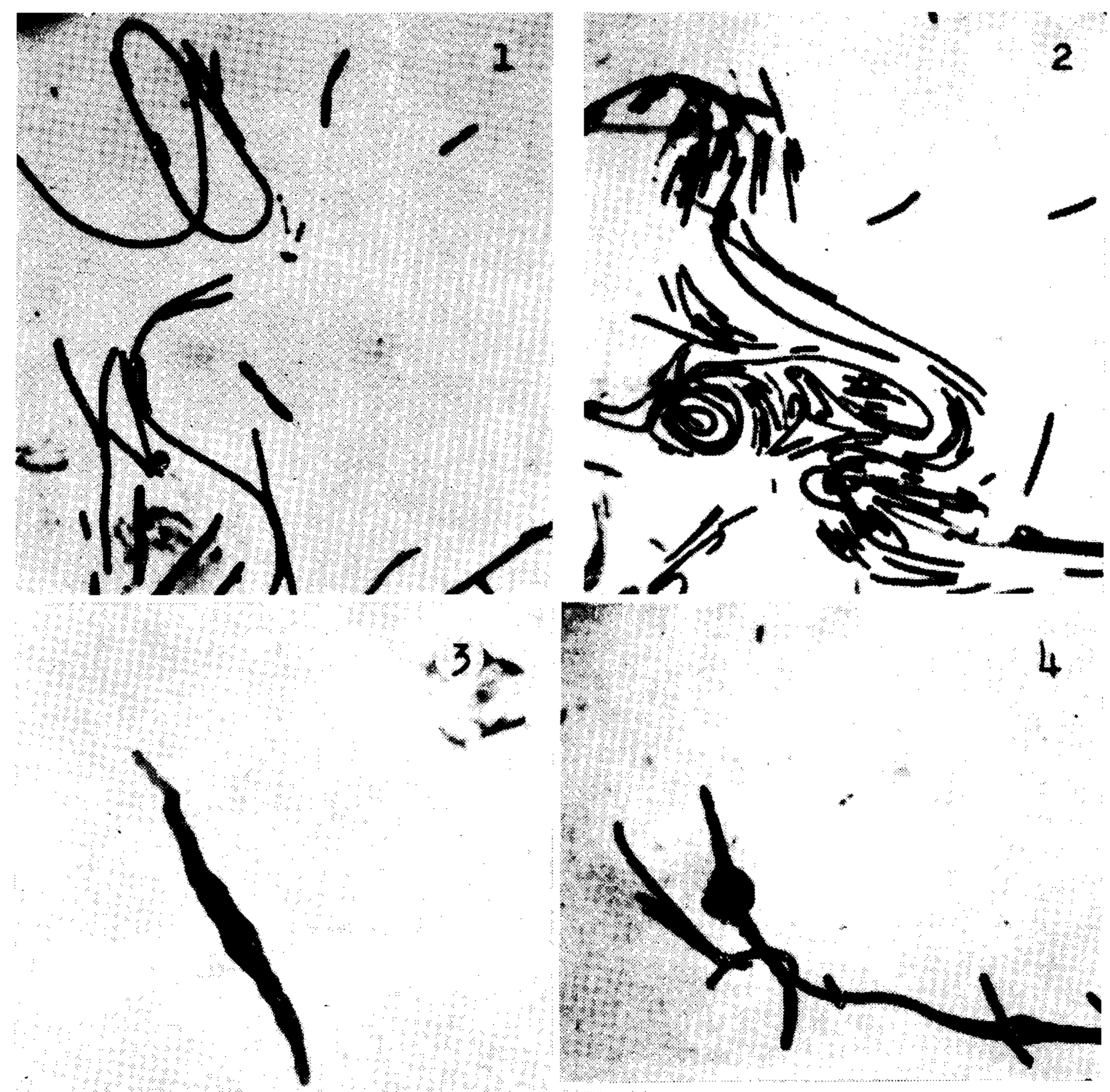

5
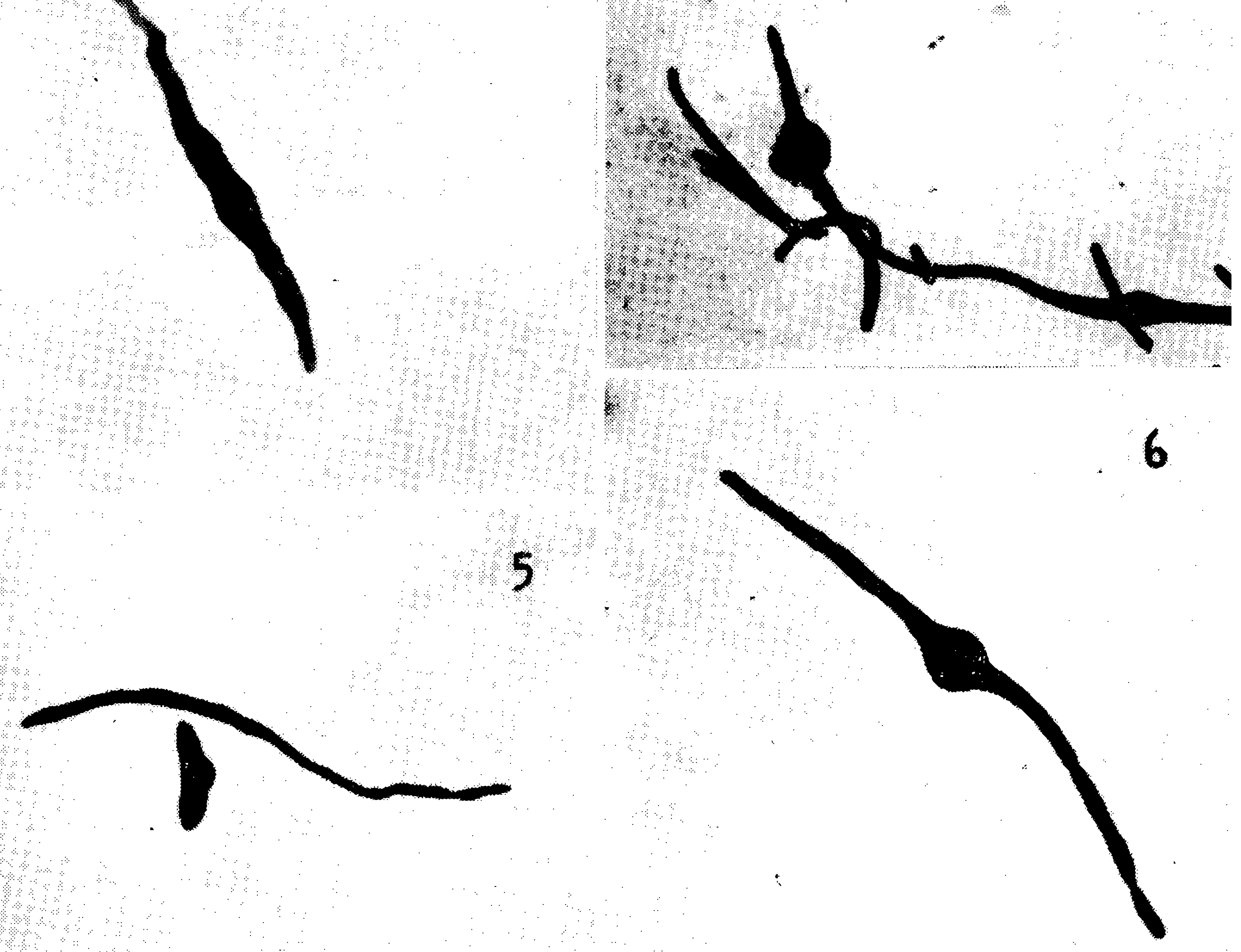

Silva \& Palmeira: Ciclo "L" em Proteus vulgaris 
ESTAMPA II

Fig. 7 - Proteus vulgaris em Meio de Monod e Wollman, com $500 \mathrm{U} / \mathrm{ml}$ de penicilina e 2 hs de crescimento a $37^{\circ} \mathrm{C}$ - Coloração de massas nucleares (Smith) $(1440 \mathrm{X})$. •

Fig. 8 - Proteus vulgaris em Meio de Monod e Wollman, com $500 \mathrm{U} / \mathrm{ml}$ de penicilina e $4 \mathrm{hs}$ de crescimento a $37^{\circ} \mathrm{C}$ - Coloração de massas nucleares (Smith) (1440 X).

Fig. 9 - Proteus vulgaris em Meio de Monod e Wollman, com $500 \mathrm{U} / \mathrm{ml}$ de penicilina e 6 hs de crescimento a $37^{\circ} \mathrm{C}$ - Coloração de massas nucleares (Smith) (1440X).

Fig. 10 - Proteus vulgaris em Meio de Monod e Wollman, com $500 \mathrm{U} / \mathrm{ml}$ de penicilina e $8 \mathrm{hs}$ de crescimento a $37^{\circ} \mathrm{C}$ - Coloração de massas nucleares (Smith) (1440 X). 
Mem. Inst. Oswaldo Cruz

ESTAMPA II

70 (1): 69-75 - 1972

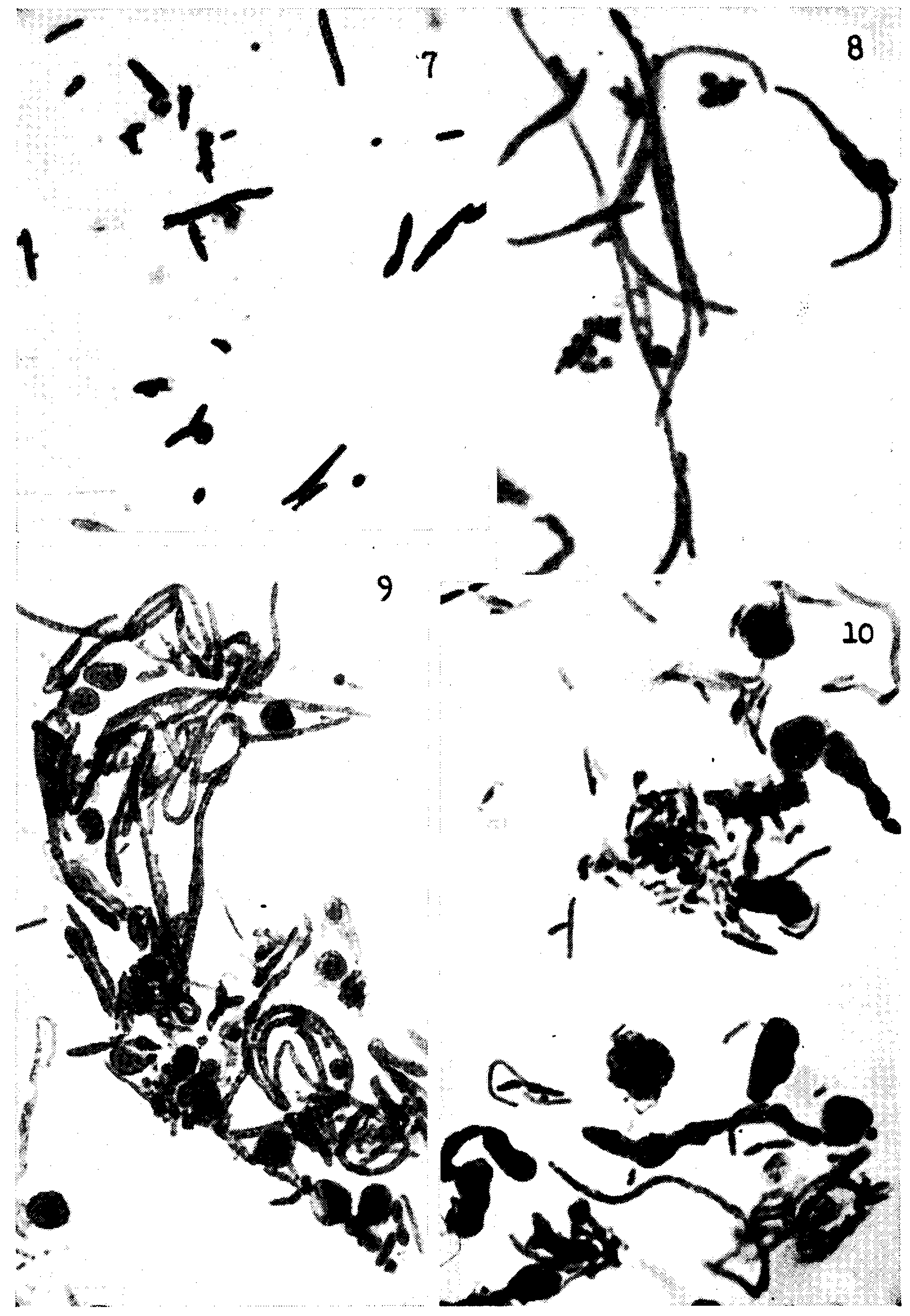

Silva \& Palmeira: Ciclo "L" em Proteus vulgaris 
ESTAMPA III

Fig. 11 - Proteus vulgaris em Meio de Abrams, com $500 \mathrm{U} / \mathrm{ml}$ de penicilina e $2 \mathrm{hs}$ de crescimento a $37^{\circ} \mathrm{C}$ - Coloração cio massas nucleares (Smith) $(1440 \mathrm{X})$.

Fig. 12 - Proteus vulgaris em Meio de Abrams. com $500 \mathrm{U} / \mathrm{nil}$ de peniciiina e 4 hs de crescimento a $37^{\circ} \mathrm{C}$ - Coloração de massas nucleares (Śmith) $(1440 \mathrm{X})$.

Fig. 13 - Proteus vulgaris em Meio de Abrams. com $500 \mathrm{U} / \mathrm{ml}$ de penicilina e 6 hs de crescimento a $37^{\circ} \mathrm{C}$ - Coloração de massas nucleares (Smith. $(1440 \mathrm{X})$.

Fig. 14 - Proteus vulgaris em Meio de Abrams, com $500 \mathrm{U} / \mathrm{ml}$ de penicilina e 6 hs de crescimento a $37^{\circ} \mathrm{C}$ - Coloração de massas nucleares (Smith) $(1440 \mathrm{X})$. 


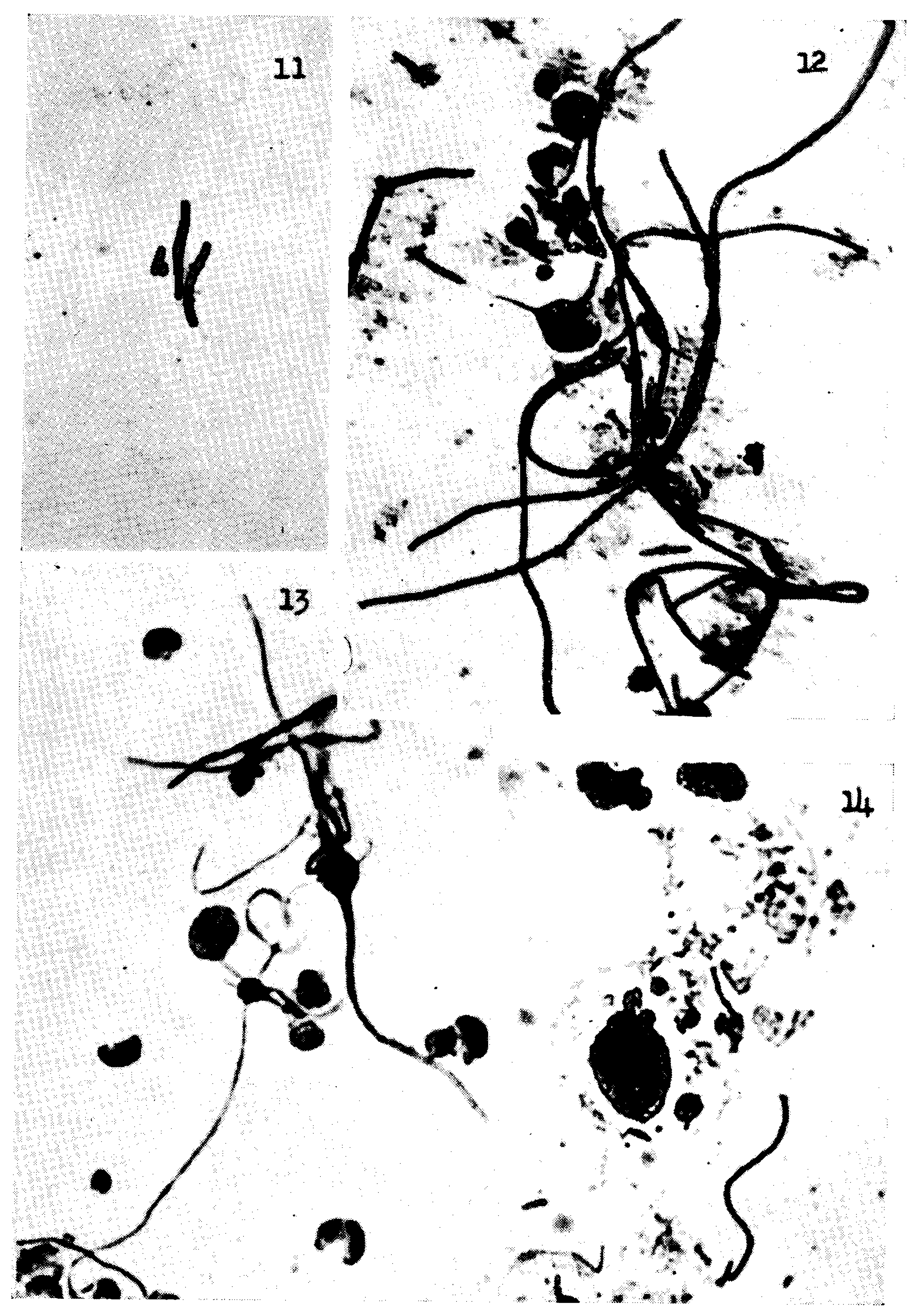

Silva \& Palmeira: Ciclo "L" em Proteus vulgaris 
Fig. 15 - Proteus vulgaris em Meio de Monod e Wollman, com $500 \mathrm{U} / \mathrm{ml}$ de penicilina e $24 \mathrm{hs}$ de crescimento a $37^{\circ} \mathrm{C}$ - Coloração de massas nucleares (Smith) (1440 X).

Fig. 16 - Proteus vulgaris em Meio de Abrams, com $500 \mathrm{U} / \mathrm{ml}$ de penicilina e $24 \mathrm{hs}$ de crescimento a $3^{\circ} \mathrm{C}$ - Coloração de massas nucleares (Smith) (1440X).

Fig. 17 - Proteus vulgaris em Meio de Monod e Wollman, com $10.000 \mathrm{U} / \mathrm{ml}$ de penicilina e $6 \mathrm{hs}$ de crescimento a $3^{\circ} \mathrm{C}$ - Coloração de massas nucleares (Smith) (1440X).

Fig. 18 - Proteus vulgaris em Meio de Monod e Wollman, com $10.000 \mathrm{U} / \mathrm{ml}$ de penicilina e 24 hs de crescimento a $37^{\circ} \mathrm{C}$ - Coloração de massas nucleares (Smith) $(1440 \mathrm{X})$. 


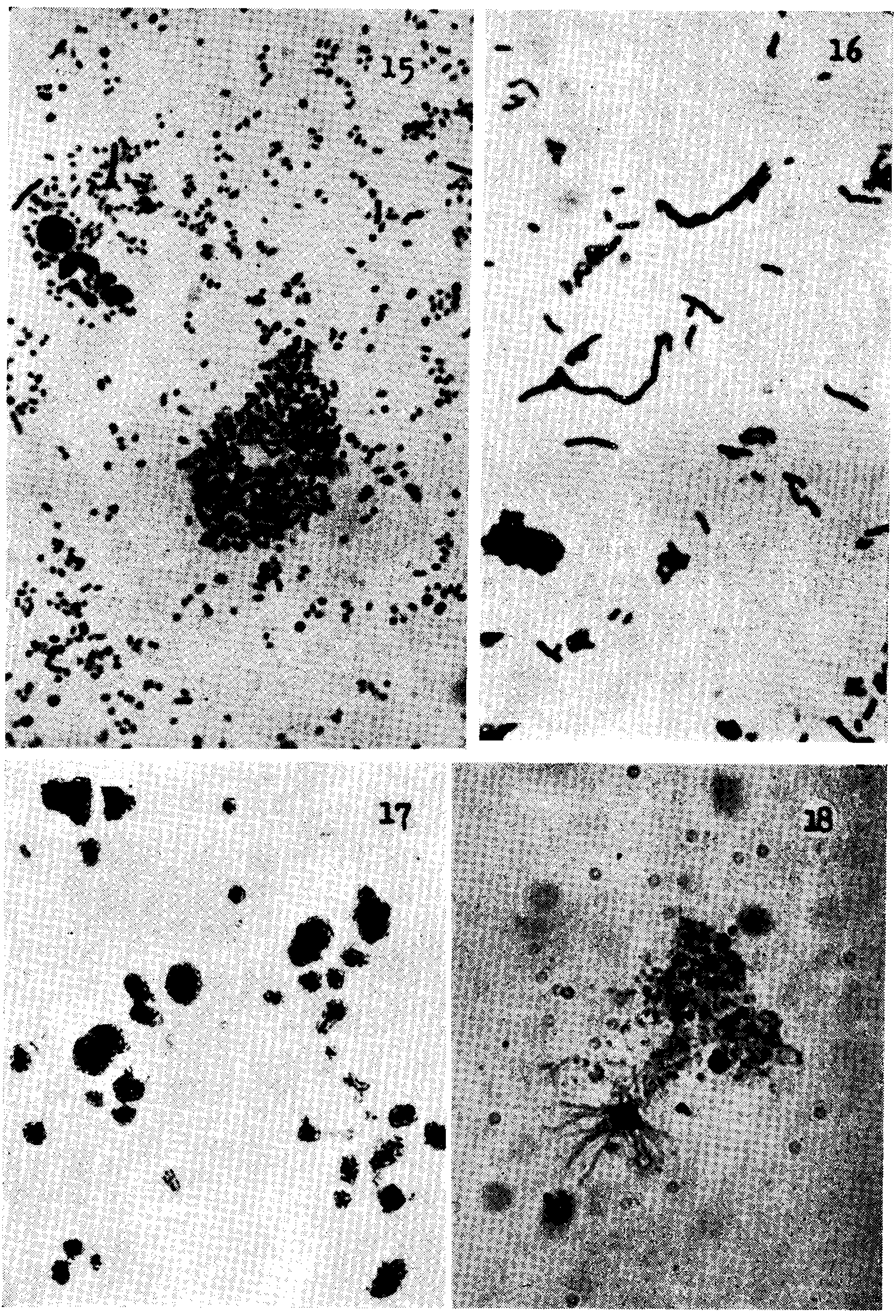

Silva \& Palmeira: Ciclo "L" em Proteus vuigaris 


\section{ESTAMPA V}

Fig. 19 - Colônia de Proteus vulgaris em Meio de Monod e Wollman, com 12 $\mathrm{U} / \mathrm{ml}$ de penicilina e 7 dias de crescimento a $37^{\circ} \mathrm{C}$.

Fig. 20 - Colônia de Proteus vulgaris em Meio de Monod e Wollman, com 12 $\mathrm{U} / \mathrm{ml}$ de penicilina e 15 dias de crescimento a $37^{\circ} \mathrm{C}$.

Figs. 21, 22 e 23 - Colônias de Proteus vulgaris em Meio de Monod e Wollman, com $12 \mathrm{U} / \mathrm{ml}$ de penicilina e 18 dias de crescimento a $37^{\circ} \mathrm{C}$. 
Mem. Inst. Oswaldo Cruz

70 (1): 69-75 - 1972

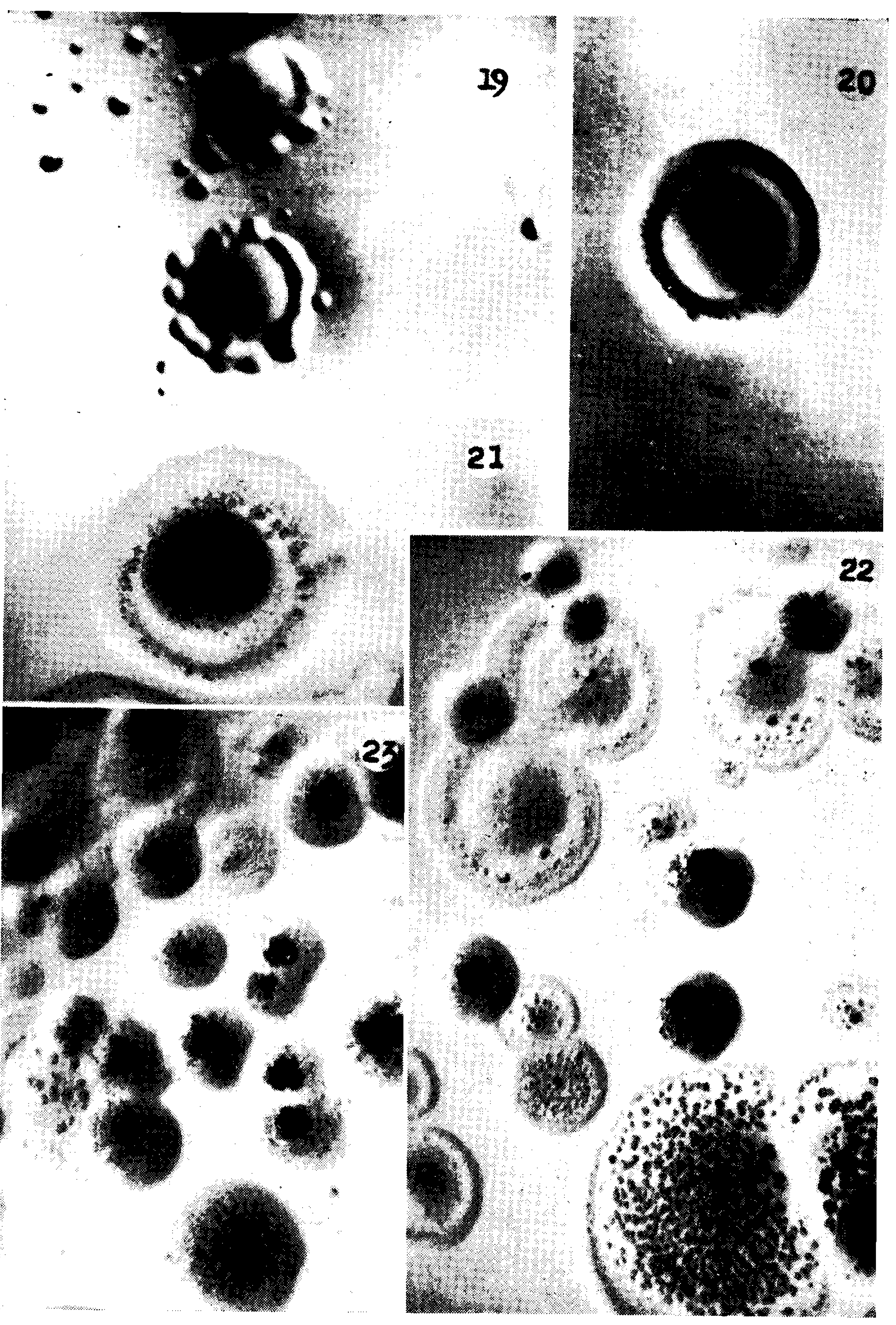

Silva \& Palmeira: Ciclo "L" em Proteus vulgaris 


\section{ESTAMPA VI}

Figs. 24, 25, 25 e 27 - Colônias de Proteus vulgaris em Meio de Monod e Wollman, com $12 \mathrm{U} / \mathrm{ml}$ de penicilina e 18 dias de crescimento a $37^{\circ} \mathrm{C}$. 
70 (1): 69-75 -1972
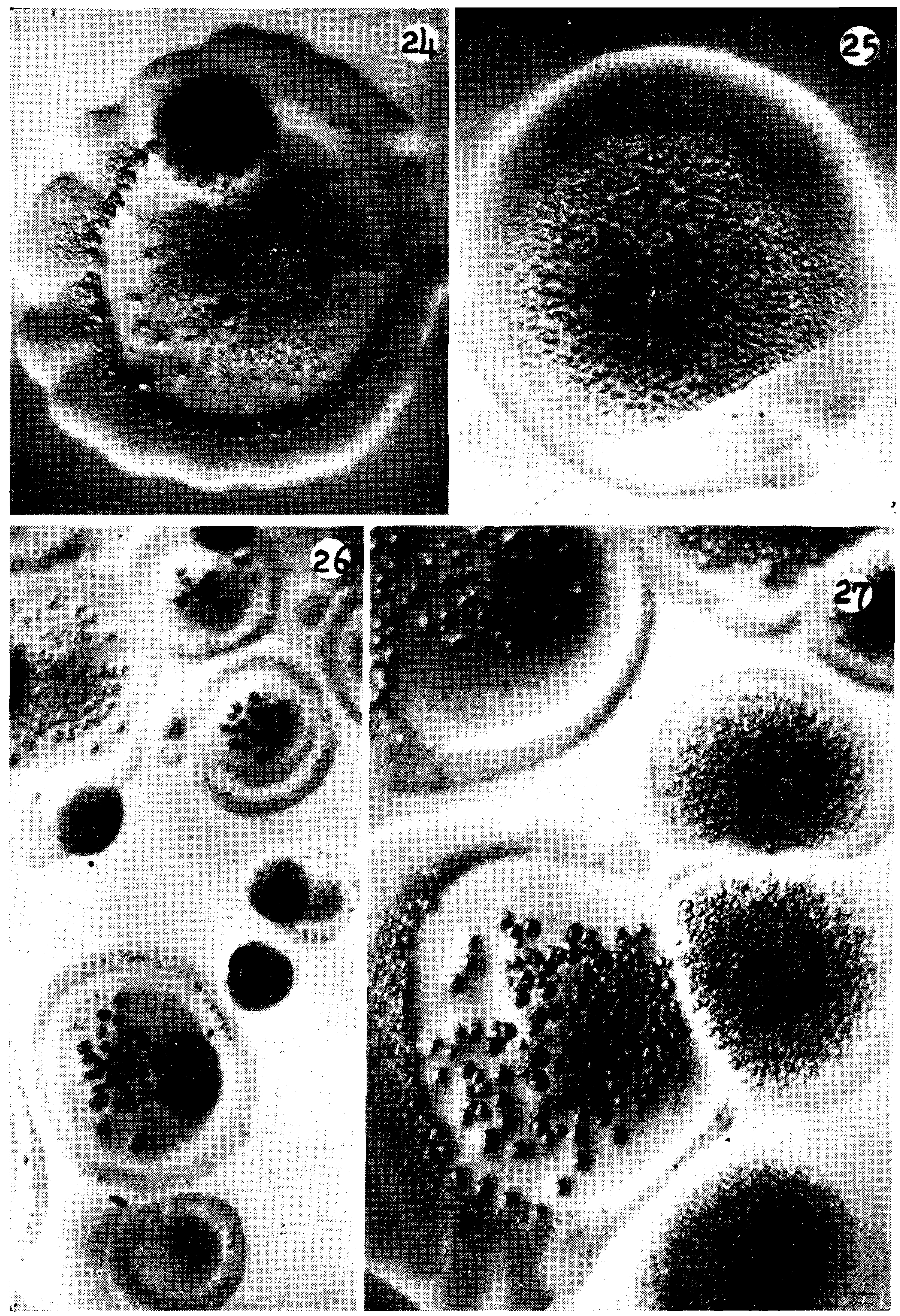

Silva \& Palmeira: Ciclo "L" em Proteus vulgaris 